\title{
Breeding biology of the Grey-headed Bulbul Pycnonotus priocephalus (Aves: Pycnonotidae) in the Western Ghats, India
}

\author{
Peroth Balakrishnan
}

Division of Conservation Ecology, Sálim Ali Centre for Ornithology and Natural History, Anaikatty, Coimbatore, Tamil Nadu 641108, India \& Wildlife Research and Conservation Trust, c/o. Anupallavi, Chungathara, Nilambur, Kerala 679334, India Current address: Department of Zoology, NSS College, Manjeri, Kerala 676122, India

Email: baluperoth@gmail.com

Date of publication (online): 26 January 2011 Date of publication (print): 26 January 2011 ISSN 0974-7907 (online) | 0974-7893 (print)

Editor: Ignacy Kitowski

\section{Manuscript details:}

Ms \# 02381

Received 02 January 2010

Final received 05 November 2010

Finally accepted 20 December 2010

Citation: Balakrishnan, P. (2011). Breeding biology of the Grey-headed Bulbul Pycnonotus priocephalus (Aves: Pycnonotidae) in the Western Ghats, India. Journal of Threatened Taxa 3(1): 1415-1424.

Copyright: (c) Peroth Balakrishnan 2011 Creative Commons Attribution 3.0 Unported License. JoTT allows unrestricted use of this article in any medium for non-profit purposes, reproduction and distribution by providing adequate credit to the authors and the source of publication.

Author Details: see end of this article.

Acknowledgements: This study was funded by the Ministry of Environment and Forests, Government of India. Logistical support and permission to use field stations were provided by the Forests and Wildlife Department of Kerala. I am grateful to Drs. V.S. Vijayan, L. Vijayan, R. Sankaran (late), P.A. Azeez, P. Pramod, T.V. Sajeev, L.D.C. Fishpool, K.S.A Das, S. Manchi and D. Mukherjee and M. Vimal for generous support and discussions during the study. I am obliged to Drs. K. Swarupanandan, N. Venkatasubramanian, K. Kunhikannan, V.S. Ramanchandran and T.S. Nayar and P.S. Jothish and S. Suresh for help with plant identification. Karuppusamy, Jose, Mohandas, Mahesh, Sainudheen, Kaliappan and Mari provided field assistance. I am grateful to Drs. V.S. Vijayan, Will Cresswell, N.S. Sodhi, G. Ritchison, N.V. Joshi, K.S.A. Das and A.P. Zaibin, T.N. Bindu and anonymous reviewers for helpful comments on earlier versions of the manuscript.

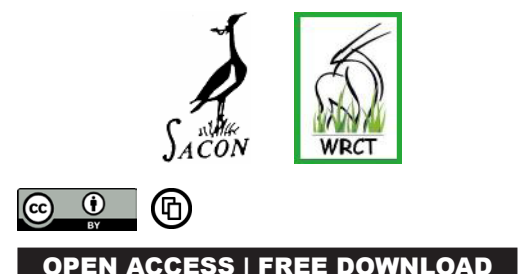

Abstract: The breeding biology of the endemic Grey-headed Bulbul Pycnonotus priocephalus was studied from 2003 to 2005 in Silent Valley National Park, Western Ghats, India. Nests were located during three field seasons from the arrival (December) to the dispersal of the birds (June) and collected data on various breeding parameters, availability of fruits and weather conditions. All nests were found in mid-elevation evergreen forests ranging from 900 to $1,400 \mathrm{~m}$ elevation. Breeding occurred in the drier months (January-May), which coincides with high fruit availability. Nest building lasted 3-8 days. Majority of the nests $(>72 \% ; n=39)$ were built on two plant species (Ochlandra travancorica and saplings of Syzygium sp.) and the mean nest height was $1.52 \pm 0.80 \mathrm{~m}(n=52)$. Nests were randomly oriented around the nesting plants with a mean vector of orientation equaling $160.45^{\circ}$. The clutch size averaged $1.53 \pm 0.50$ eggs (range $=1-2 ; n=47)$. Incubation and nestling periods were $13 \pm 0.87(n=9)$ and $12 \pm$ $0.50(n=9)$ days, respectively. Overall nest success was $10.79 \%$. Nest success rates varied among incubation and nestling periods. Grey-headed Bulbul exhibit life-history traits associated with low productivity such as short breeding season, low clutch size, fewer broods per year and high predation rates indicating that deterioration of breeding habitats might seriously hamper the long-term survival of the species.

Keywords: Breeding biology, Grey-headed Bulbul, life-history traits, nesting success, Pycnonotus priocephalus, Silent Valley, tropical forests, Western Ghats.

\section{INTRODUCTION}

Information on life history traits, especially for rare species, are essential for estimating and understanding population growth rates (Stahl \& Oli 2006), and predicting responses to environmental changes to be able to develop appropriate conservation management strategies (Martin 1996; Newton 1998; BirdLife International 2000; Both \& Visser 2005). Yet, breeding biology and life history traits of most tropical birds are poorly known and large groups like bulbuls are no exception (Stutchbury \& Morton 2001; Fishpool \& Tobias 2005).

The family Pycnonotidae (bulbuls) comprises about 140 species and 355 taxa, widespread in southern Asia, Africa, Madagascar and islands of the western Indian Ocean (Sibley \& Monroe 1990; Fishpool \& Tobias 2005; Woxwold et al. 2009). The reproductive traits of only a few widespread and lowland pycnonotids have been studied in Asia and Africa (e.g., Liversidge 1970; Vijayan 1975, 1980; Walting 1983; Ali \& Ripley 1987; Hsu \& Lin 1997; Kruger 2004; Fishpool \& Tobias 2005).

Here, I report the first study of the reproductive biology of the Grey-headed Bulbul, Pycnonotus priocephalus (Image 1), one of the 16 restricted-range bird species of the Western Ghats, southern India 


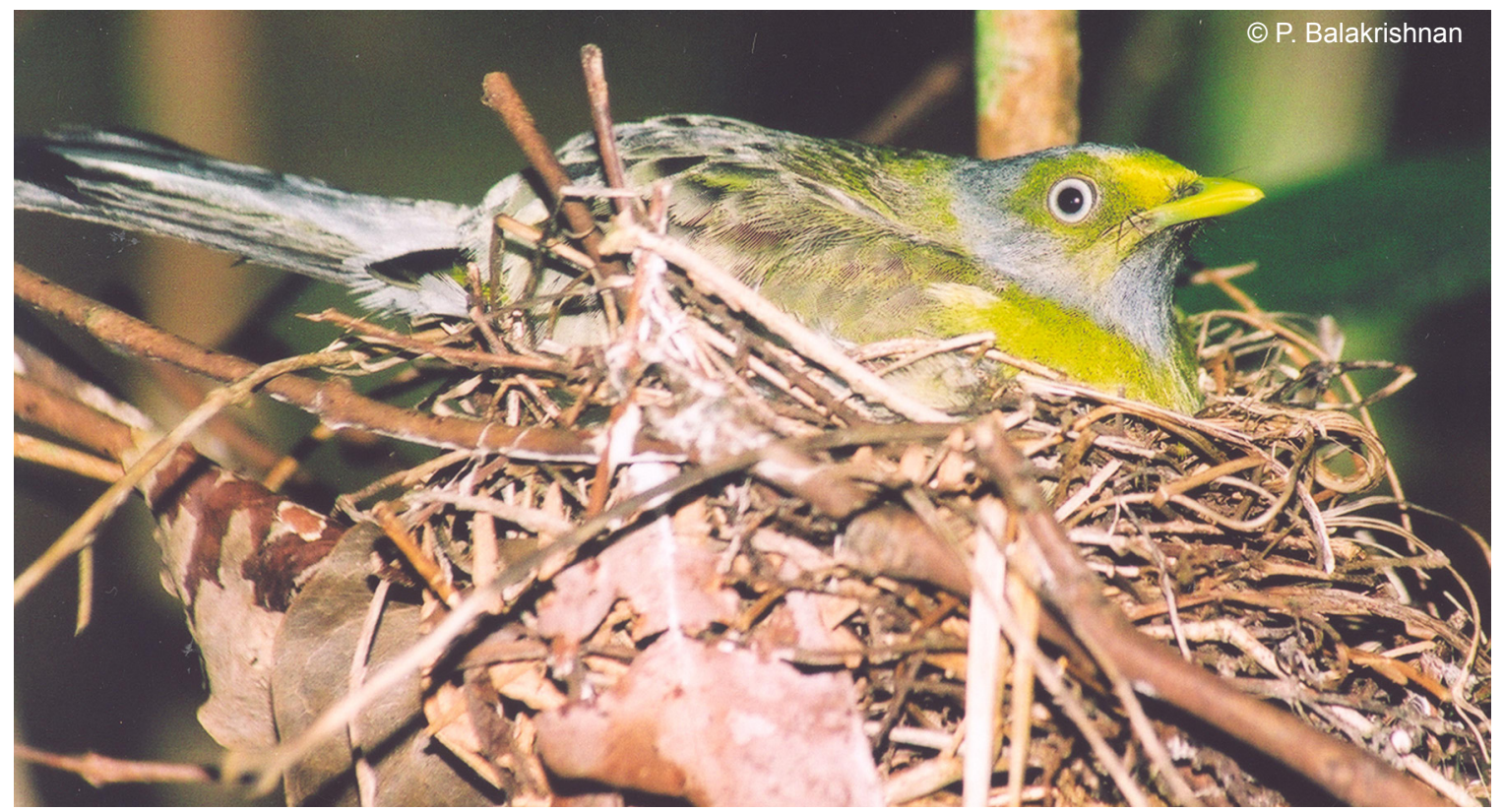

Image 1. Grey-headed Bulbul Pycnonotus priocephalus, the study species.

(Stattersfield et al. 1998). It has a very limited distribution in the heavy rainfall areas along the southwestern side of India from Belgaum and Goa south through Kerala including the Nilgiris, Palnis, western Mysore and Coorg from plains to $1,400 \mathrm{~m}$ (Ali \& Ripley 1987; Balakrishnan 2007). Although Greyheaded Bulbuls are reported from the moist deciduous, scrub, and evergreen forests in the rain shadow areas, the breeding of the species is restricted to the midelevation west coast tropical evergreen forests (c. $50 \mathrm{~km}^{2}$ ) between $700 \mathrm{~m}$ and $1,400 \mathrm{~m}$ in Silent Valley National Park (Balakrishnan 2007). The species was listed as Least Concern (BirdLife International 2008) based on the qualitative descriptions in Ali \& Ripley (1987) and Grimmett et al. (1998). A recent survey of the Grey-headed Bulbul along the Western Ghats revealed rarity and natural patchy occurrence within evergreen forests and seasonal altitudinal movements (Balakrishnan 2007). Following this the species has been uplisted to Near Threatened category (BirdLife International 2010). Owing to these attributes together with continuing habitat loss and degradation, it is essential to understand key life history traits including developmental periods and survival rates of Greyheaded Bulbul. The objectives of the present study was to obtain information on the breeding season, nesting plants, nest placement, clutch sizes, developmental periods, nesting success and causes of nest failures and compare this information with available data for other bulbuls.

\section{MATERIALS AND METHODS}

\section{Study area}

This study was conducted in the core area of Silent Valley National Park $\left(11^{\circ} 00^{\prime}-11^{0} 15^{\prime} \mathrm{N} \& 7^{0} 15^{\prime}\right.$ $76^{0} 35^{\prime} \mathrm{E}$, area: $89.52 \mathrm{~km}^{2}$, elevation: $658-2,383 \mathrm{~m}$ ) in the Western Ghats, India, during January 2003 through May 2005. The climate is typically tropical, with mean annual rainfall above $5,000 \mathrm{~mm}$, which falls mostly during the south-west monsoon period (MaySeptember). January to March are comparatively drier months. From June to December the relative humidity is often high, around 95\%. The mean maximum and minimum temperatures at Silent Valley during the study period were $25.8^{\circ} \mathrm{C}$ and $19.8^{\circ} \mathrm{C}$, respectively. The general vegetation in the area is typical wet evergreen with montane sholas (forests) and grasslands at higher elevations. Within the study sites, the distribution and breeding of Grey-headed Bulbul was recorded only in the evergreen forests. The vegetation in the breeding habitat is dominated by large evergreen trees such as Cullenia exarillata, Canarium strictum, Calophyllum elatum, Elaeocarpus serratus, Myristica dactyloides, Mesua ferrea, Elaeocarpus munronii, Syzygium 
spp., Palaquium ellipticum, Persea macrantha and Poeciloneuron sp. The sub-canopy and understorey is dominated by species such as Clerodendrum viscosum, Maesa indica, Chloranthus brachystachys, Ochlandra travancorica and several Strobilanthes species.

\section{Field methods}

I located and monitored nests of Grey-headed Bulbul during three breeding seasons from the arrival (December) to the dispersal of the birds (June) in 2003 through 2005. I recorded 20, 23 and 25 pairs of Grey-headed Bulbul from the intensive study area during 2003, 2004 and 2005 breeding seasons respectively and a total of 54 nests during this period. Since the species is extremely shy and finding nests from the large stretch of understorey patches was very difficult, most of the nests were located by observing the behaviour of adult birds (carrying nest materials and food and frequent visits to certain patches; Martin \& Guepel 1993). Breeding seasonality was determined from the nesting records of each month during three years. To examine whether the seasonal variation in fruit availability influences the timing of breeding, I monitored 25 plant species that comprised $>90 \%$ of their fruit diet in two transects of 2,000 x $20 \mathrm{~m}$. These plants include 15 trees (Antidesma menasu, Callicarpa tomentosa, Clerodendrum viscosum, Allophyllus cobbe, Litsea floribunda, Litsea stocksii, Olea dioica, Oreocnide integrifolia, Persea macrantha, Symplocos cochinchinensis, Symplocos racemosa, Syzygium cumini, Syzygium sp., Viburnum sp. and Ziziphus rugosa), six shrubs (Chloranthus brachystachyus, Lantana camara, Leea indica, Maesa indica, Psychotria nigra and Polygonam chinense), three lianas (Rubia cordifolia, Rubus ellipticus and Smilax sp.) and one epiphyte (Scurrola parasitica). I quantified the number of species and percent of individuals fruiting per month as an indicator of fruit availability. Weather data were collected from the Walakkad forest station of the Kerala Forests and Wildlife Department.

The breeding status including the dates of nest construction, egg laying, incubation and nestlings were recorded every day for each nest found. Nest contents were determined by using a mirror and pole for inaccessible nests. Nests that fledged at least one young were considered successful. Observations of fledgling in or near nest, or parents feeding new fledglings in the general area of the nest were taken as evidence of a successful nest. Depredation was assumed when eggs or nestlings (when too young to fledge) disappeared (Martin \& Roper 1988). Various aspects of nest placement such as nest plant species, nest height (height of the nest above ground), relative height (height of nest above ground divided by the height of the plant) and height of nesting plant were measured in the field immediately after the fledging of the young. Orientation of the nests relative to the main stem was recorded for all nests. Compass bearings of nests were recorded to the nearest degree using a Suunto MCA-D compass.

\section{Data analysis}

The influence of temperature, rainfall and availability of fruits on the breeding season was tested using Spearman rank correlation (Zar 1999). Nesting success of Grey-headed Bulbul was estimated from 47 intensively monitored nests by different methods. First, I calculated the apparent nesting success (number of successful nests divided by the total number of nests found). Second, I calculated the reproductive success as an index of the chick fledged versus eggs laid (see Vijayan 1980; Jehle et al. 2004), and finally, I used the Mayfield estimator (Mayfield 1975) to calculate the daily mortality and survival rates and nesting success. The daily mortality rate $(\mathrm{m})$ was calculated by dividing the number of clutches that failed to survive by the total number of days all nests were under observation and exposed to loss. The daily survival rates (DSR) were calculated as, 1-number of failed nests/number of exposure days. Then, to obtain an estimate of nest survival over the entire nesting period, the daily survival rate is raised to the power equivalent to the average number of days (d) in the nesting period as, nest survival $=(D S R)^{d}$. Nest survival for the entire nesting period and for incubation and nestling periods were calculated separately. The variance $(v)$ and standard error (SE) are approximated for the estimator of daily survival probabilities by following Johnson (1979) and Hensler (1985).

The null hypothesis of uniform distribution of nest orientation in all directions was tested by using Rao's spacing test (Zar 1999). Watson-Williams F test was used to test the variations in the orientations of moss and vine nests and successful and failed nests (Batschelet 1981; Bergin 1991; Zar 1999). Circular 
statistics were computed using the statistical package Oriana (Kovach Computing Services 2004, Version 2.01c) and other analyses were performed using SPSS (SPSS Inc. 1999, Version 10.0). Results are reported as Mean \pm SE values and a probability level of $\leq 0.05$ was considered statistically significant and $\leq 0.01$ was considered highly significant. The summary statistics for circular data are presented as mean vector $(\mu \pm$ $\left.\mathrm{SE}^{0}\right)$.

\section{RESULTS}

\section{Breeding season}

The Grey-headed Bulbul began arriving at the study sites by the third week of December. The breeding activities were commenced in January and the first egg laying dates were 2, 10 and 26 January for 2003, 2004 and 2005 breeding seasons respectively. I found 47 nests of Grey-headed Bulbul, 14, 15 and 18 nests during 2003, 2004 and 2005 breeding seasons respectively from Silent Valley. Additionally, seven more nests were located in the surrounding reserved forests (Nilambur and Mannarkkad forest divisions), but not included in the analysis except for nest placement attributes. Peak egg laying was observed in early April during 2004 and 2005 while it was in late March during 2003 (Fig. 1). The breeding season (January-May) of the species was positively correlated with maximum temperature (Spearman's $\mathrm{r}=0.660, \mathrm{n}=$ $29, \mathrm{p}<0.01$ ), number of species with fruits (Spearman's

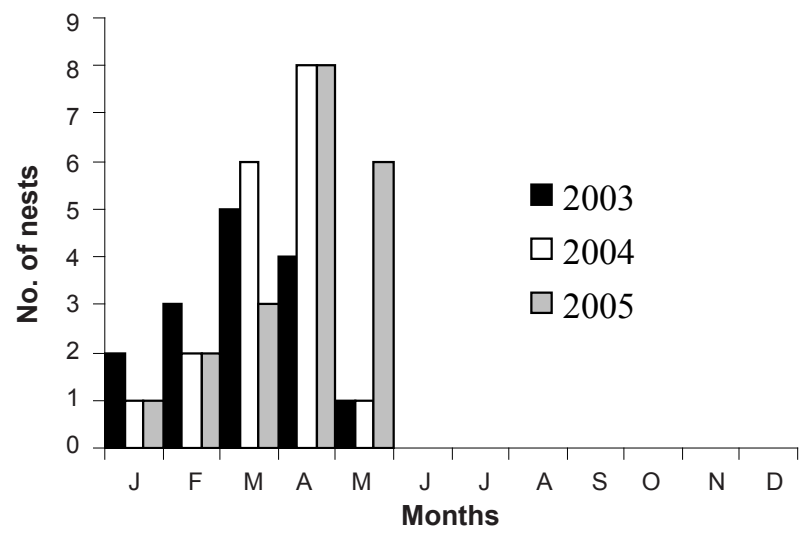

Figure 1. Breeding season of Grey-headed Bulbul based on the number of clutches initiated per month during 20032005 at Silent Valley National Park

$\mathrm{r}=0.895, \mathrm{n}=27, \mathrm{p}<0.01$; Fig. 2 ) and $\%$ of individuals monitored fruited (Spearman's $r=0.761, n=27, p<$ 0.01 ; Fig. 2) and inversely correlated with the monthly rainfall (Spearman's $\mathrm{r}=-0.373, \mathrm{n}=29, \mathrm{p}<0.05$; Fig. 3). Although a negative trend exists, number of nests per month was not statistically correlated with the number of rainy days per month (Spearman's $\mathrm{r}=$ $-0.350, \mathrm{n}=29, \mathrm{p}=0.063$; Fig. 3).

\section{Nest structure, placement and orientation}

Three types of nests were constructed based on the variation in the microhabitat. The dominant ( $\mathrm{n}=$ 35) typical bulbul nests (hereafter: vine nests) were made mainly of vines and grasses and seen mostly in Strobilanthes patches. Second type of nests (hereafter: moss nests) constructed mainly with Ochlandra leaves

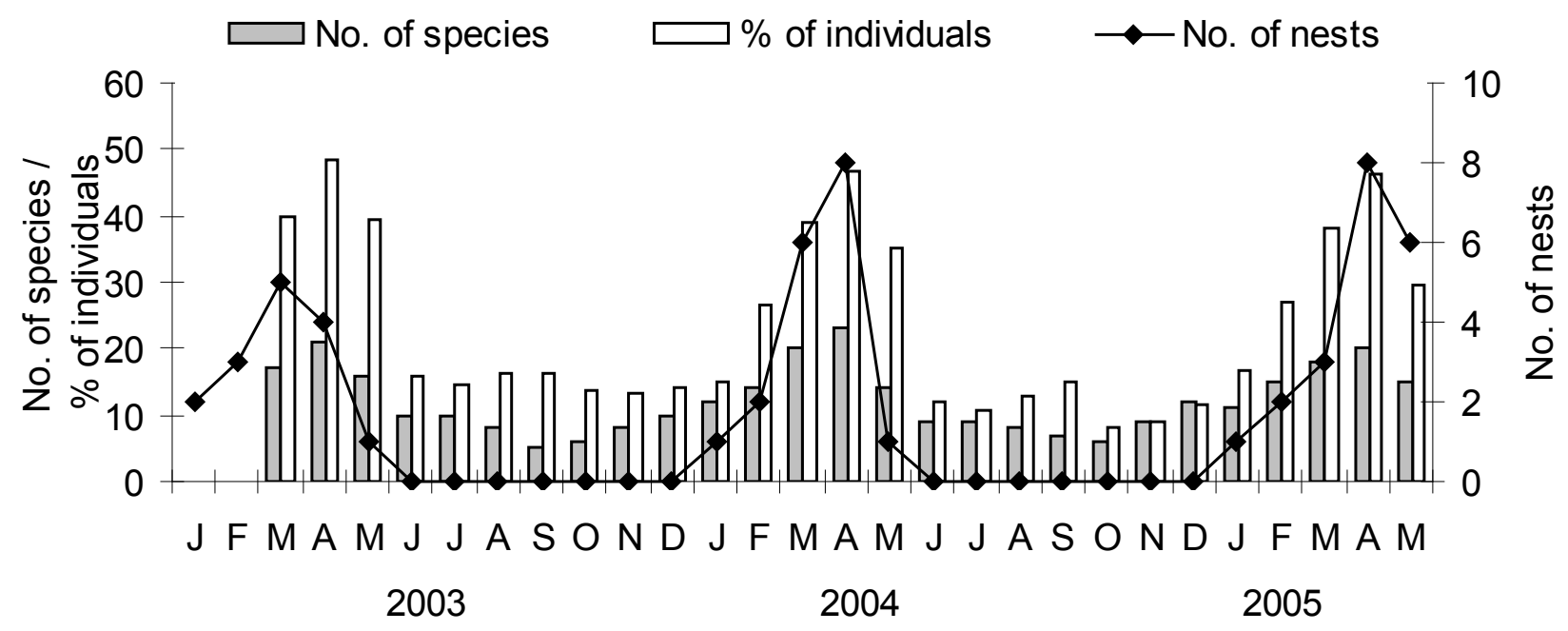

Figure 2. Relationship between breeding seasonality of Grey-headed Bulbul with the fruiting phenology of 25 major food plants at Silent Valley National Park. 


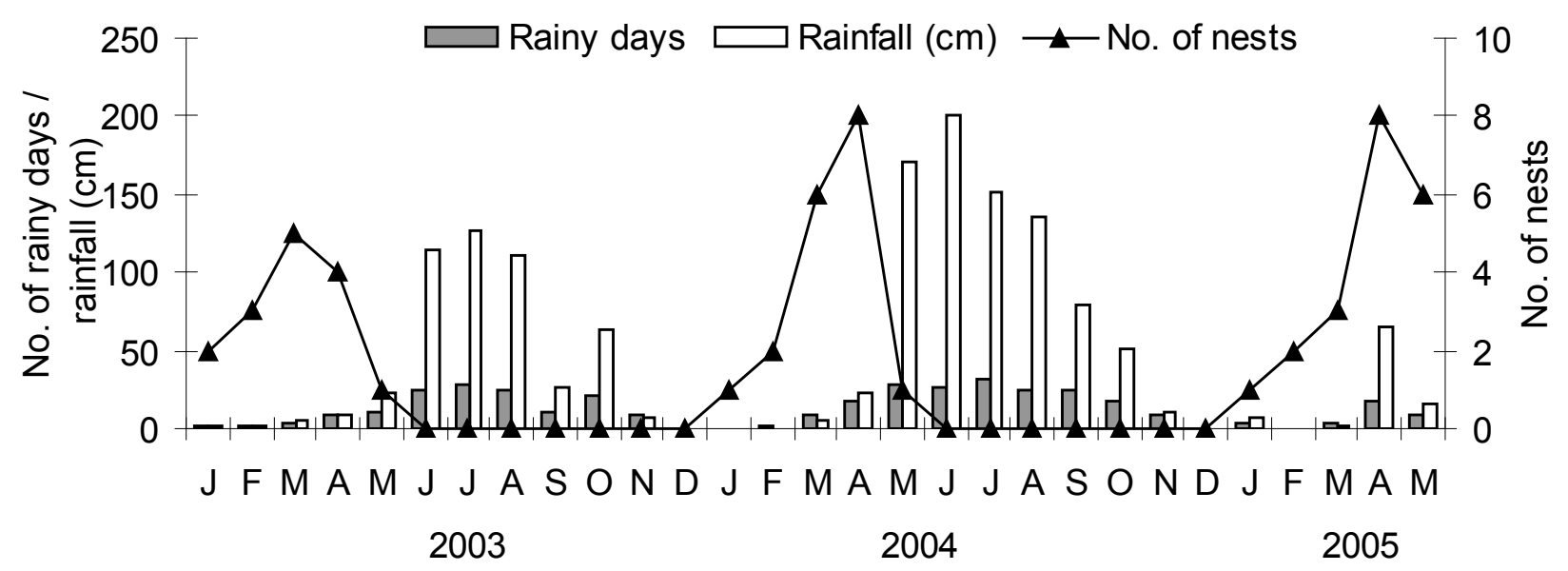

Figure 3. Relationship between clutch initiations of Grey-headed Bulbul with monthly rainfall and number of rainy days/ month at Silent Valley National Park.

and green moss $(\mathrm{n}=18)$ were located mostly in reedbamboo (Ochlandra travancorica) patches. A single nest, of a third type made with fresh green leaves was also recorded (Table 1). The construction time varied considerably between the two major nest types, 3-5 days for the vine nests $(n=4)$ and 6-8 days for moss nests $(n=2)$.

Grey-headed Bulbul used 12 plant species for nesting. Nests were located on live plants except the four nests placed on dead branches of Ochlandra travancorica, Strobilanthes foliosus and sapling of Syzygium sp. Ochlandra travancorica $(\mathrm{n}=21,38.89 \%)$ and saplings of Syzygium sp. $(\mathrm{n}=18,33.33 \%)$ were the most used plant species, followed by Calamus pseudotenuis ( $\mathrm{n}=3$ ), Lasianthus jackianus, Thottea siliquosa, and an un-identified shrub (two each) Oreocnide integrifolia, Antidesma menasu, Saprosma glomerata, Strobilanthes foliosus, Sarcococca coriacea and an unidentified sapling (one each). All the moss nests except one recorded on Strobilanthes foliosus were on Ochlandra travancorica. Of the 35 vine nests, 18 were on saplings of Syzygium sp.

The nests were $1.52 \pm 0.80 \mathrm{~m}$ (range $=0.52-4.8 \mathrm{~m}$, $\mathrm{n}=52$ ) above the ground, and at a mean relative height of $0.61 \pm 0.20($ range $=0.18-1.00, \mathrm{n}=52)$. All the nests were placed in the junctions of multiple branches, closer to the central stem except for the nests placed on Oreocnide integrifolia and Sarcococca coriacea. In general, there was no significant difference in the nest height (ANOVA: $\mathrm{F}_{2,48}=0.737, \mathrm{p}=0.484$ ), height of nesting plant (ANOVA: $\mathrm{F}_{2,48}=0.353, \mathrm{p}=0.705$ ), and relative nest height (ANOVA: $\mathrm{F}_{2,48}=0.879, \mathrm{p}=$
0.422 ) between the breeding seasons. Nest placement attributes significantly varied between the moss and vine nests. The moss nests had higher nest heights $\left(2.29 \pm 0.20 \mathrm{~m}\right.$ vs $1.08 \pm 0.05 \mathrm{~m}$; ANOVA: $\mathrm{F}_{1,48}=$ $51.540, \mathrm{p}<0.001)$ and were placed on taller plants compared to the vine nests $(4.17 \pm 0.33 \mathrm{~m}$ vs $1.90 \pm$ $0.15 \mathrm{~m}$; ANOVA: $\left.\mathrm{F}_{1,48}=51.281, \mathrm{p}<0.001\right)$. However, there was no difference in the relative nest heights between the moss and vine nests $(0.59 \pm 0.05$ vs 0.63 \pm 0.03 ; ANOVA: $\left.\mathrm{F}_{1,48}=0.939, \mathrm{p}=0.337\right)$.

Nests were significantly non-uniformly oriented with clear avoidance of the north side of the nesting plants (mean vector, $\mu \pm \mathrm{SE}=160.45 \pm 9.23^{\circ}$; Rao's spacing test: $\mathrm{U}=227.5, \mathrm{n}=48, \mathrm{p}<0.01)$. Nest orientation deviated significantly from random for both moss (Mean vector, $\mu \pm \mathrm{SE}=190.88 \pm 14.50^{\circ}$; Rao's spacing test, $U=180, p<0.05)$ and vine nests (Mean vector, $\mu \pm \mathrm{SE}=147.01 \pm 10.91^{0}$; Rao's spacing test, $\mathrm{U}=207.5, \mathrm{p}<0.01)$ and slightly differed between two nest types (Watson-Williams test: $\mathrm{F}_{1,45}=5.56, \mathrm{p}$ $=0.023)$. There was no variation in nest orientation between the successful (Mean Vector, $\mu \pm \mathrm{SE}=141.26$ $\pm 27.25^{\circ}$ ) and failed nests (Mean vector, $\mu \pm \mathrm{SE}=$ $164.13 \pm 9.72^{0}$; Watson-Williams test: $\mathrm{F}_{1,46}=0.864$, $\mathrm{p}=0.358$ ). In general, the nests were placed in the leeward side of the nesting plants.

\section{Clutch size and developmental periods}

The average clutch size of Grey-headed Bulbul was $1.53 \pm 0.50$ eggs (range $=1-2$ eggs, $n=47$ ), with $53 \%$ of nests with two and remaining with one egg. Of the 31 vine nests monitored, $71 \%$ of nests were 


\begin{tabular}{|l|c|c|c|c|c|c|c|c|}
\hline Nesting parameters & \multicolumn{2}{|c|}{2003} & \multicolumn{2}{c|}{2004} & \multicolumn{2}{c|}{2005} & \multicolumn{2}{c|}{ Pooled } \\
\hline & No. & $\%$ & No. & $\%$ & No. & $\%$ & No. & $\%$ \\
\hline Total nests & 14 & & 15 & & 18 & & 47 & \\
Moss nests & 6 & 42.86 & 4 & 26.67 & 5 & 27.78 & 15 & 31.91 \\
Vine nests & 7 & 50.00 & 11 & 73.33 & 13 & 72.22 & 31 & 65.96 \\
Leaf nests & 1 & 7.14 & 0 & 0 & 0 & 0 & 1 & 2.13 \\
\hline Nest with two eggs & 8 & 57.14 & 6 & 40.00 & 11 & 61.11 & 25 & 53.19 \\
\hline Nest with one egg & 6 & 42.86 & 9 & 60.00 & 7 & 38.89 & 22 & 46.81 \\
\hline Total eggs monitored & 22 & & 21 & & 29 & & 72 & \\
\hline Egg predationldestruction & 9 & 40.91 & 16 & 76.19 & 23 & 79.31 & 48 & 66.67 \\
\hline Chick hatched & 13 & 59.09 & 5 & 23.81 & 6 & 20.69 & 24 & 33.33 \\
\hline Chick predation & 2 & 15.38 & 2 & 40.00 & 5 & 66.67 & 9 & 37.50 \\
\hline Chick fledged & 11 & 84.62 & 3 & 60.00 & 1 & 16.67 & 15 & 62.50 \\
\hline Overall nesting success* & & 50.00 & & 14.29 & & 3.45 & & 20.83 \\
\hline
\end{tabular}

Table 1. Breeding performance of Greyheaded Bulbul in Silent Valley National Park during 2003-2005.

*calculated as an index of chick fledged versus eggs laid.

with one egg and remaining with two eggs each. All the moss nests monitored $(n=15)$ produced two eggs each. There was a significant reduction in the clutch size by advance of the breeding season (Spearman's $\mathrm{r}=-0.457, \mathrm{n}=46 ; \mathrm{p}<0.001)$. One egg was laid per day, and incubation started with the last egg.

The mean incubation period for all the nests for which a complete record is available from the clutch completion to hatching was $13.00 \pm 0.87$ days (range $=$ 12-14 days, $n=9)$. Nestlings spent an average of 12 \pm 0.50 days (range $=11-13$ days, $n=9$ ) in the nest. The overall period for incubation to fledgling lasted a mean of $25 \pm 0.89$ days (range $=24-26$ days, $\mathrm{n}=$ $6)$. Thus the entire breeding cycle including the nest construction, egg laying and developmental periods completed within a month.

\section{Nest success}

Nine of 47 nests $(19.15 \%)$ monitored fledged young, with successful nests producing $1.67 \pm 0.50$ young/nest. Apparent nesting success (successful nests/total nests found) varied significantly between the breeding years. The highest percentage of nesting success was in 2003 (42.86\%), while it was $13.33 \%$ and $5.56 \%$ during 2004 and 2005, respectively. A total of 15 chicks were fledged from 72 eggs of 47 nests (20.83\%). Egg mortality was quite heavy (66.67\%) owing to high predation and varied significantly between breeding seasons. Out of 72 eggs laid, only $24(33.33 \%)$ were hatched. Nine chicks disappeared from the nests due to predation (Table 1). Using
Mayfield's method, the daily survival rates were 0.899 \pm 0.017 and $0.958 \pm 0.018$ during the incubation and nestling periods, respectively, and $0.915 \pm 0.013$ overall. The Mayfield nest success was $24.97 \%$ and $60.01 \%$ during the incubation and nestling periods, respectively, and $10.79 \%$ for the overall nesting period. Nest success differed among years, 32\%, 5.69\% and $4.53 \%$ respectively, for 2003, 2004 and 2005 breeding seasons (Table 2). There was no significant variation in the egg survival among the moss $(25.42 \%)$ and vine nests $(22.33 \%)$. However, chicks of moss nests had a significantly better chance of surviving the nestling period $(100 \%)$ than vine nests $(34.55 \%)$. Consequently, the overall nesting success of moss nests $(16.66 \%)$ was significantly higher than the vine nests (6.52\%, Table 3). Apparent nesting success also varied between the moss nests $(26.67 \%$ of 15 nests) and vine nests ( $12.9 \%$ of 31 nests). The single leaf nest found in 2003 successfully fledged two chicks. More than $90 \%$ of the nest failures were due to predation and trampling. Nest predation was characterized by complete loss of the clutch or brood.

\section{DISCUSSION}

Breeding of open-country Pycnonotus species have been recorded in all months and some are known quite commonly to raise $3-5$ broods in a year while breeding activities in the montane forest species tends to be suppressed during the wet and coldest months (Ali 
Table 2. Nest survival for Grey-headed Bulbul in different reproductive stages and breeding seasons.

\begin{tabular}{|c|c|c|c|c|c|c|c|}
\hline $\begin{array}{l}\text { Reproductive period / Year } \\
\text { (No. of nests monitored) }\end{array}$ & $\begin{array}{l}\text { No. of } \\
\text { successful } \\
\text { nests }\end{array}$ & $\begin{array}{l}\text { Nest } \\
\text { exposure } \\
\text { days }\end{array}$ & DMR $^{\text {a }}$ & $\mathrm{DSR} \pm \mathrm{SE}{ }^{\mathrm{b}}$ & $\begin{array}{l}\text { Nest survival } \\
\text { variance }\end{array}$ & $\begin{array}{c}95 \% \\
\text { confidence } \\
\text { interval }^{c}\end{array}$ & $\begin{array}{l}\text { Mayfield nest } \\
\text { success }\end{array}$ \\
\hline Incubation (47) & 14 & 326 & 0.101 & $0.899 \pm 0.017$ & $2.791 \times 10^{-4}$ & $0.866,0.932$ & 24.97 \\
\hline Nestling (14) & 9 & 120 & 0.042 & $0.958 \pm 0.018$ & $3.328 \times 10^{-4}$ & $0.923,0.994$ & 60.01 \\
\hline Overall nesting (47) & 9 & 446 & 0.085 & $0.915 \pm 0.013$ & $1.748 \times 10^{-4}$ & $0.889,0.941$ & 10.79 \\
\hline $2003(14)$ & 6 & 180 & 0.044 & $0.956 \pm 0.015$ & $2.359 \times 10^{-4}$ & $0.925,0.987$ & 32 \\
\hline 2004 (15) & 2 & 102 & 0.108 & $0.892 \pm 0.028$ & $8.050 \times 10^{-4}$ & $0.836,0.947$ & 5.69 \\
\hline 2005 (18) & 1 & 155 & 0.116 & $0.884 \pm 0.027$ & $7.047 \times 10^{-4}$ & $0.832,0.936$ & 4.53 \\
\hline
\end{tabular}

Nest exposure days are the total number of days that active nests were monitored; a DMR - daily mortality rate; ${ }^{b} \mathrm{DSR}$ - daily survival rate; ${ }^{\mathrm{c}} \mathrm{Confidence}$ interval for daily probability of nest survival.

\begin{tabular}{|c|c|c|c|}
\hline \multirow{2}{*}{$\begin{array}{l}\text { Reproductive } \\
\text { period }\end{array}$} & \multirow{2}{*}{ Estimated parameter } & \multicolumn{2}{|c|}{ Mean \pm SE } \\
\hline & & $\begin{array}{c}\text { Moss nest } \\
n=15\end{array}$ & $\begin{array}{c}\text { Vine nest } \\
n=31\end{array}$ \\
\hline Incubation & $\begin{array}{l}\text { Daily survival rate } \\
\text { Egg survival variance } \\
95 \% \text { confidence interval } \\
\text { Percent success }\end{array}$ & $\begin{array}{l}0.900 \pm 0.029 \\
8.182 \times 10^{-4} \\
0.844,0.956 \\
25.42\end{array}$ & $\begin{array}{l}0.891 \pm 0.022 \\
4.804 \times 10^{-4} \\
0.848,0.934 \\
22.33\end{array}$ \\
\hline Nestling & $\begin{array}{l}\text { Daily survival rate } \\
\text { Chick survival variance } \\
95 \% \text { confidence interval } \\
\text { Percent success }\end{array}$ & $\begin{array}{l}1.000 \pm 0.000 \\
0.000 \\
1.000,1.000 \\
100\end{array}$ & $\begin{array}{l}0.915 \pm 0.036 \\
1.315 \times 10^{-3} \\
0.844,0.986 \\
34.55\end{array}$ \\
\hline Overall nesting & $\begin{array}{l}\text { Daily survival rate } \\
\text { Nest survival variance } \\
95 \% \text { confidence interval } \\
\text { Percent success }\end{array}$ & $\begin{array}{l}0.931 \pm 0.020 \\
4.050 \times 10^{-4} \\
0.891,0.970 \\
16.66\end{array}$ & $\begin{array}{l}0.897 \pm 0.019 \\
3.554 \times 10^{-4} \\
0.860,0.933 \\
6.52\end{array}$ \\
\hline
\end{tabular}

Table 3. Daily survival probabilities of eggs and nestlings and percentage nesting success for the incubation, nestling and overall nesting periods estimated using Mayfield's method for the different nest types of Grey-headed Bulbul in Silent Valley National Park.

\& Ripley 1987; Fishpool \& Tobias 2005). Breeding of Grey-headed Bulbul is highly seasonal (JanuaryMay; Fig. 1) and coincides with high fruit availability and absence of high rainfall (Fig. 2, 3). The general breeding patterns of the bird community at Silent Valley was also highly seasonal during the study period (Das 2008; P. Balakrishnan pers. obs.). Moreover, the breeding season of south Indian passerines is strongly related to the pre-monsoon during May to June, a month before the peak monsoon (Pramod \& Yom-Tov 1999), so that the peak food demand of chicks coincides with the arrival of the monsoon (Ali \& Ripley 1987). The heavy rainfall during longer south-west (JuneSeptember) monsoon may also restrict the breeding of open-cup nesting species to the drier months. The general fruiting pattern in Silent Valley National Park shows a bi-modal pattern with a higher peak during the late summer-early south-west monsoon (March-May) and a smaller peak in the early north-west monsoon (November-December) (Balakrishnan 2007). On the other hand, food plant species of Grey-headed Bulbul showed a single peak which coincides with the first peak of general fruiting and breeding season of the study species. Thus, fruit availability is an important factor deciding the breeding season of Grey-headed Bulbul however, further studies on the availability of other food sources such as caterpillars are required to understand relative importance of weather conditions and food abundance in determining the timing of breeding.

Nesting plant selection by Grey-headed Bulbul seems to be adaptive. Of the 12 plant species used for nesting, two species (Ochlandra travancorica and saplings of Syzygium sp.) together bear about $72 \%$ of nests. Besides giving enough support for nest placement, high foliage cover on the Ochlandra provides a camouflaging background to the moss nests. On the other hand, the liana draped Syzygium saplings with a dull background form a better camouflaged environment for the vine nests (background matching 
hypothesis: Martin 1988; Filliater et al. 1994; Hansell 2000). The differential nest placement attributes of Grey-headed Bulbul in Ochlandra and Strobilanthes patches are also adaptive to the respective microhabitats. The moss nests in the Ochlandra patches are placed above $2 \mathrm{~m}$ well inside the foliage and thus camouflaged from the predators. On the other hand, the nests in the Strobilanthes patches are placed around one meter height in a pale background surrounded by dry stems and lianas. However, in both the habitats, nests were placed in the middle of the nesting plants. The nonuniform orientation of nests around the nest plants was towards the leeward directions of the nest sites and orientation did not affect the outcome of the nests.

The nest construction period of Grey-headed Bulbul (3-8 days) was similar to that of other species (Redvented Bulbul Pycnonotus cafer: 2-5 days, Yellowthroated Bulbul Pycnonotus xantholaemus: 3-8 days, Cape Bulbul Pycnonotus capensis: 2-10 days; see Ali \& Ripley 1987; Fishpool \& Tobias 2005). Similarly the incubation (13 days) and nestling periods (12 days) of Grey-headed Bulbul fall within the range of the developmental periods reported for pycnonotids (1114 days and 10-13 days for incubation and nestling periods, respectively; Vijayan 1975, 1980; Ali \& Ripley 1987; Fishpool \& Tobias 2005; P. Balakrishnan pers. obs.). In most of the African and Asian species of bulbuls, the clutch usually consists of two or three eggs and many species known to lay four or five eggs (Ali \& Ripley 1987; Fishpool \& Tobias 2005). The average clutch size of Grey-headed Bulbul was 1.53 \pm 0.50 eggs with half of the nests producing a single egg (Table 1). This is one of the lowest clutch size reported for the pycnonotids (Ali \& Ripley 1987; Fishpool \& Tobias 2005). Intra-seasonal decline in the clutch size, which is a commonly observed pattern in several tropical and temperate birds (Hamann \& Cooke 1989; Doligez \& Clobert 2003), was also observed for the study species. The role of different mechanisms hypothesized to explain the clutch size reduction including seasonal variation in the food availability and predator abundance (Hamann \& Cooke 1989; Martin 1992; Doligez \& Clobert 2003) needs further experimental studies.

Since the bulbuls were not colour marked, the estimation of the nesting attempts per year was unclear. Available data suggests that Grey-headed Bulbul is a single-brooded passerine, although, possibility of a replacement brood is not ruled out. Moreover, in spite of the extensive search in all territories, the number of nests recorded was fewer than the total number of pairs recorded in all the breeding seasons.

The overall Mayfield nest success of Grey-headed Bulbul was low at $10.79 \%$ (with $24.97 \%$ for egg stage and $60.01 \%$ for the nestling stage; Table 2) compared to that of Yellow-browed Bulbul Iole indica and Squaretailed Black Bulbul Hypsipetes ganeesa which breeds in the same habitat (Balakrishnan 2009; 2010). Some authors have reported higher predation rates during the nestling period (reviewed in Martin 1992). However, I found higher predation during the egg stage as reported by others (e.g., Mermoz \& Reboreda 1998). Nest predation rates of Grey-headed Bulbul appear to be significantly higher than that of the average rates (71\%) recorded for the open cup-nesting tropical birds (Robinson et al. 2000; Stutchbury \& Morton 2001). In southern India, the nesting success of lowland bulbuls was reported as $13.2 \%$ ( 15 chicks out of 114 eggs) for White-browed Bulbul Pycnonotus luteolus and 8.3\% (11 chicks out of 134 eggs) for Red-vented Bulbul (Vijayan 1975, 1980) and, this figure drops to $8 \%$ in the introduced population of Red-vented Bulbul in Fiji (Walting 1983). However, these studies are conducted in highly disturbed habitats and the species are known to raise several broods per year (Vijayan 1980; Ali \& Ripley 1987; Fishpool \& Tobias 2005). The nest losses of Grey-headed Bulbul were mainly caused by predation and trampling by large mammals such as Asian Elephant Elephas maximus and Sambar Deer Cervus unicolor. Nests in the Ochlandra patches, which are a major feeding ground for the elephants, seemed to be highly vulnerable. In the present study the direct evidence of predation is restricted to a single observation of egg predation by Jungle Striped Squirrel Funambulus tristriatus. The potential nest predators at the study site include White-bellied Treepie Dendrocitta leucogastra, Rufous Treepie Dendrocitta vagabunda, Greater Coucal Centropus sinensis, and Asian Koel Eudynamys scolopacea, Indian Rat Snake Ptyas mucosa, Common Vine Snake Ahaetulla nasuta and several species of small mammals and snakes. Brood parasitism is a major problem for a number of African bulbuls (Krüger 2004) and two species of Asian bulbuls (Fishpool \& Tobias 2005). However, no brood parasitism was observed in the Grey-headed Bulbul nests during this study. 
The results of the present study show that timing of breeding and developmental periods of Grey-headed Bulbul is similar to that of many congeners or other tropical species. However, they exhibit several life history traits associated with low productivity such as relatively short breeding season, low clutch size (lowest in the genus), less number of broods per year and nesting failures due to predation. These atypical reproductive traits along with the restricted range, patchiness in occurrence and large-scale loss of lowland habitats in Western Ghats (Menon \& Bawa 1997; Stattersfield et al. 1998; Mittermeier et al. 1999) suggests that any further deterioration of the breeding habitats might seriously hamper the long-term survival of Grey-headed Bulbul. Further research on the life history traits including the age of first reproduction, adult and juvenile survival and breeding success in other sites is also required before recommendations on effective conservation measures can be made.

\section{REFERENCES}

Ali, S. \& S.D. Ripley (1987). Handbook of the Birds of India and Pakistan. Compact edition, Oxford University Press, New Delhi, 737pp.

Balakrishnan, P. (2007). Status, distribution and ecology of the Grey-headed Bulbul Pycnonotus priocephalus in the Western Ghats, India. PhD Thesis. Bharathiar University, Coimbatore, India, xvi $+223 p p$.

Balakrishnan, P. (2009). Breeding biology and nest site selection of Yellow-browed Bulbul Iole indica in Western Ghats, India. Journal of the Bombay Natural History Society 106(2): 176-183.

Balakrishnan, P. (2010). Reproductive biology of the squaretailed Black Bulbul Hypsipetes ganeesa in the Western Ghats, India. Indian Birds 5(5): 134-138.

Batschelet, E. (1981). Circular Statistics in Biology. Academic Press, London, 371pp.

Bergin, T.M. (1991). A comparison of goodness-of-fit tests for analysis of nest orientation in Western Kingbirds (Tymnnus verticalis). Condor 93: 164-171.

BirdLife International (2000). Threatened Birds of the World. Lynx Edicions and BirdLife International, Cambridge, 852pp.

BirdLife International (2008). Species fact sheet: Pycnonotus priocephalus. <www.birdlife.org>. Downloaded on 15 February 2009.

BirdLife International (2010). Species factsheet: Pycnonotus priocephalus. Downloaded from $<$ http://www.birdlife.org $>$ Downloaded on 25 October 2010.

Both, C. \& M.E. Visser (2005). The effect of climate change on the correlation between avian life-history traits. Global Change Biology 11: 1606-1613.

Das, K.S.A. (2008). Bird community structure along the altitudinal gradient in Silent Valley National Park, Western Ghats, India. PhD Thesis. Bharathiar University, Coimbatore.

Doligez, B. \& J. Clobert (2003). Clutch size reduction as a response to increased nest predation rate in the Collared Flycatcher. Ecology 84: 2582-2588.

Filliater, T.S., R. Breitwisch \& P.M. Nealen (1994). Predation on northern cardinal nests: does choice of site matter? Condor 96: 761-768.

Fishpool, L.D.C. \& J.A. Tobias (2005). Family Pycnonotidae (bulbuls), pp. 124-253. In: del Hoyo, J., A. Eliott \& D.A. Christie (eds.). Handbook of the Birds of the World. Vol. 10, Lynx Edicions, Barcelona, 896pp.

Grimmett, R., C. Inskipp \& T. Inskipp (1998). Birds of the Indian Subcontinent. Cristopher Helm-A \& C Black Ltd, London, 384pp.

Hamann, J. \& F. Cooke (1989). Intra-seasonal decline of clutch size in Lesser Snow Geese. Oecologia 79: 83-90.

Hansell, M.H. (2000). Bird Nests and Construction Behaviour. Cambridge University Press, Cambridge, 288pp.

Hensler, G.L. (1985). Estimation and comparison of functions of daily nest survival probabilities using the Mayfield method, pp. 289-301. In: Morgan B.J.T. \& P.M. North (eds.). Statistics in Ornithology.Springer-Verlag, New York, 418 pp.

Hsu, M.J. \& Y.-S. Lin (1997). Breeding ecology of Styan's Bulbul Pycnonotus taivanus in Taiwan. Ibis 139: 518-522.

Jehle, G., A.A.Y. Adams, J.A. Savidge \& S.K. Skagen (2004). Nest survival estimation: a review of alternatives to the Mayfield estimator. Condor 106: 472-484.

Johnson, D.H. (1979). Estimating nest success: the Mayfield method and an alternative. Auk 96: 651-661.

Krüger, O. (2004). Breeding biology of the Cape Bulbul Pycnonotus capensis: a 40-year comparison. Ostrich 75: 211-216.

Liversidge, R. (1970). The Ecological Life History of the Cape Bulbul. PhD Thesis. University of Cape Town, Cape Town, South Africa.

Martin, T.E. (1988). On the advantage of being different: Nest predation and the coexistence of bird species. Proceedings of the National Academy of Sciences 85: 2196-2199.

Martin, T.E. (1992). Interaction of nest predation and food limitation in reproductive strategies. Current Ornithology 9: 163-197.

Martin, T.E. (1996). Life history evolution in tropical and south temperate birds: what do we really know? Journal of Avian Biology 27: 263-272.

Martin, T.E. \& J.J. Roper (1988). Nest predation and nest site selection in a western population of the Hermit Thrush. Condor 90: 51-57.

Martin, T.E. \& G.R. Geupel (1993). Nest-monitoring plots: methods for locating nests and monitoring success. Journal of Field Ornithology 64: 507-519. 
Mayfield, H. (1975). Suggestions for calculating nest success. Wilson Bulletin 87: $456-466$.

Menon, S. \& K.S. Bawa (1999). Applications of geographical information systems, remote sensing and a landscape ecology approach to biodiversity conservation in the Western Ghats. Current Science 73: 134-145.

Mermoz, M.E. \& J.C. Reboreda (1998). Nesting success in brown-and-yellow Marshbirds: effects of timing, nest site, and brood parasitism. Auk 115: 871-878.

Mittermeier, R.A., N. Myers \& C.G. Mittermeier (1999). Hotspots. Earth's Biologically Richest and Most Endangered Terrestrial Ecoregions. CEMEX and Conservation International, London, 432pp.

Newton, I. (1998). Population Limitation in Birds. Academic Press, London, 597pp.

Pramod, P. \& Y. Yom-Tov (1999). The breeding season and clutch size of Indian passerines. Ibis 142: 75-81.

Robinson, W.D., T.R. Robinson, S.K. Robinson \& J.D. Brawn (2000). Nesting success of understorey forest birds in lowland Panama. Journal of Avian Biology 31: 151-164.

Sibley, C.G. \& B.L. Monroe (1990). Distribution and taxonomy of birds of the world. Yale University Press, New Haven, 1136pp.

Stahl, J.T. \& M.K. Oli (2006). Relative importance of avian life-history variables to population growth rate. Ecological Modelling 198: 23-39.

Stattersfield, A.J., M.J. Crosby, A.J. Long \& D.C. Wege (1998). Endemic Bird Areas of The World: Priorities for Biodiversity Conservation. BirdLife International, Cambridge, 860pp

Stutchbury, B.J.M. \& E.S. Morton (2001). Behavioral Ecology of Tropical Birds. Academic Press, London, ix+164pp.

Vijayan, V.S. (1975). Ecological isolation of Bulbuls with special reference to Pycnonotus cafer cafer and P. luteolus luteolus at Point Calimere, Tamil Nadu. $\mathrm{PhD}$ Thesis. University of Bombay, Mumbai, India, 274pp.

Vijayan, V.S. (1980). Breeding biology of bulbuls, Pycnonotus cafer and Pycnonotus luteolus (Class: Aves, Family: Pycnonotidae) with special reference to their ecological isolation. Journal of the Bombay Natural History Society 75: 10901117.

Walting, D. (1983). The breeding biology of the Red-vented Bulbul Pycnonotus cafer in Fiji. Emu 83: 173-180.

Woxvold, I.A., J.W. Duckworth \& R.J. Timmins (2009). An unusual new bulbul (Passeriformes: Pycnonotidae) from the limestone karst of Lao PDR. Forktail 25: $1-12$.

Zar, J.H. (1999). Biostatistical Analysis. $4^{\text {th }}$ edition. Prentice-Hall, New Jersey, xii+664pp.
Author Details: Dr. P. BaLAKRISHnAN was a Research Fellow at SACON, Coimbatore. He is also associated with the Wildlife Research \& Conservation Trust, Nilambur. His research interests include ecology and conservation of threatened and fragmented populations, wildlife-habitat relationships, human and climate change impacts on the demography and life-history strategies of birds. 